\section{WHCLIS teleconference stimulates action plan for Colorado}

\author{
By Camila A. Alire \\ Dean, Auraria Library, University of \\ Colorado at Denver, Colorado Delegate to \\ WHCLIS, and co-chair of the Conference \\ Recommendations Committee
}

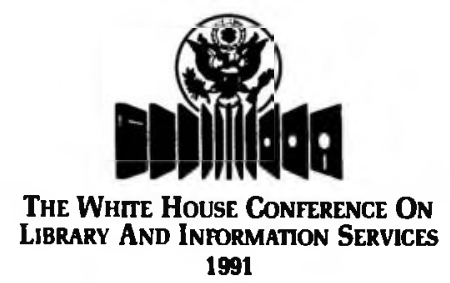

A lthough few in numbers, people in Colorado attending the White House Conference on Library and Information Services (WHCLIS) Teleconference on December 10, 1991, were representative of all categories of delegates to the White House Conference: general public, government officials, trustees, library and information professionals. The library and information professionals represented academic, public, school, and special libraries.

The WHCLIS Teleconference presented the opportunity for Colorado's delegates and others to reconvene and update their knowledge about the White House Conference. It also became the catalyst for those in attendance tosetintoaction Colorado's information agenda. State issues predominated in the minds of attendees. So much so that, after one hour of the Teleconference, Colorado tuned out! The television monitor was tumed off, and no one seemed to be concerned with the questions coming from all over the country into the national panelists. Instead, Colorado delegates wanted to talk about the recommendations from the state conference, so attention was paid to those priorities.

The group devised an action plan which has implications for academic libraries in Colorado. Interestingly enough, the attitude in the discussion was never "per library type"; it reflected instead a concern for all types of library services in Colorado.

Four committees were set up to carry through the action plan. One of the committees, the Marketing Committee, will include a joint effort of various Colorado library professional associations, private industry, Center for the Book, and other groups to market all types of libraries and library services. In addition, this committee will work on a literacy plan to promote the need for library-based literacy programs to public libraries and to private industry and government agencies. The Marketing Committee's agenda will include Colorado's user friendliness and library education priorities.

The Committee on Funding for Libraries will concentrate on seeking state aid and additional funding for all libraries. This committee will work closely with the Colorado Library Association's Legislative Committee. Networking and resourcesharing activities will be encouraged as a way for libraries to stretch their resources and funds.

The Networking/Cooperation Committee will include the work of two other committees in Colorado: ACCESS Colorado and the Colorado Strategic Planning Committee. Emphasis will be placed on better school and public library cooperation and more cooperation among special libraries.

In addition, the Coalition Building Committee (aka the Infiltration Committee) will encourage and nominate library professionals to sit on various non-library boards, committees, planning groups, etc. This committee will identify vacancies in such groups and recommend that library professionals fill those vacancies. The Coalition Building Committee will also work closely with the Colorado Council on Library Development Multicultural Task Force to identify groups and organizations that should be represented on library committees and to identify board and committee vacancies in this organization that could be filled by library professionals.

So, what about the WCHLIS Teleconference? The Teleconference became the catalyst that brought interested state delegates together to review state issues and priority recommendations and to develop an action plan. This action plan now provides the framework for Colorado to move forward with its prionities which, incidently, were also recommendations at the national level. For that, we thank the WHCLIS Teleconference and the White House Conference itself? 